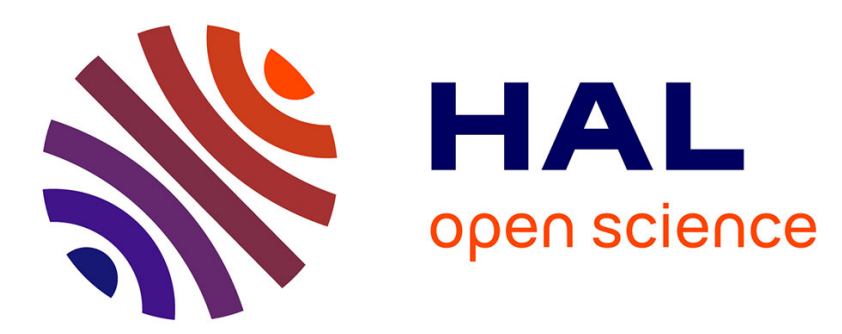

\title{
XANES study of metal/polymer interfaces : standard surface and first metallization stages
}

L. Bellard, Y. Mathey, J. Themlin, A. Cros, G. Tourillon, C. Laffon, Y. Parent

\section{To cite this version:}

L. Bellard, Y. Mathey, J. Themlin, A. Cros, G. Tourillon, et al.. XANES study of metal/polymer interfaces: standard surface and first metallization stages. Journal de Physique IV Proceedings, 1994, 04 (C9), pp.C9-221-C9-225. 10.1051/jp4:1994940 . jpa-00253501

\section{HAL Id: jpa-00253501 https://hal.science/jpa-00253501}

Submitted on 1 Jan 1994

HAL is a multi-disciplinary open access archive for the deposit and dissemination of scientific research documents, whether they are published or not. The documents may come from teaching and research institutions in France or abroad, or from public or private research centers.
L'archive ouverte pluridisciplinaire HAL, est destinée au dépôt et à la diffusion de documents scientifiques de niveau recherche, publiés ou non, émanant des établissements d'enseignement et de recherche français ou étrangers, des laboratoires publics ou privés. 


\title{
XANES study of metal/polymer interfaces: standard surface and first metallization stages
}

\author{
L. Bellard, Y. Mathey, J.M. Themlin, A. Cros, G. Tourillon*, C. Laffon* and Y. Parent* \\ URA 783 du CNRS, Faculté des Sciences de Luminy, Département de Physique, Case 901, \\ 13288 Marseille cedex 9 , France \\ * LURE, Bât. 209D, 91405 Orsay, France
}

\begin{abstract}
We have studied, by X-ray absorption near edge spectroscopy (XANES), the properties of untreated and chromium metallized surface of polyphenylquinoxaline (PPQ). Using reference compounds such as 2,2 -biquinoline, we point out that the terminal phenyl rings of the polymer are normal to the surface of pristine PPQ. Moreover, it is shown that chromium/polymer interaction induces a reorientation of these terminal phenyl rings parallel to the polymer unit mean plane.
\end{abstract}

\section{Introduction:}

Thermostable insulating polymers have become widely studied materials in microelectronics [1]. In particular, multichip modules based on 3D copper wiring networks insulated by thin polymer layers are the subject of very active research [2]. Polyphenylquinoxaline (PPQ) (Fig. 1), because of its remarkable dielectric properties $\left(\varepsilon<3, \tan \delta<10^{-3}\right)[3]$ is especially suitable for this kind of device.<smiles>Cc1ccc(-c2nc3cc(-c4ccc5nc(-c6ccccc6)c(C)nc5c4)ccc3nc2-c2ccccc2)cc1</smiles>

Fig. 1: Chemical structure of polyphenylquinoxaline.

To improve the relatively poor adhesion of copper on PPQ, we have considered two different ways of surface preparation prior to copper deposition. The first one consists in a plasma treatment of the polymer surface prior to metallization (Cu/PPQ plasma systems)[4]. The consequences of such a treatment on the XANES spectra of the polymer have been discussed elsewhere [5]. The second one consists in evaporating a thin chromium layer prior to copper deposition $(\mathrm{Cu} / \mathrm{Cr} / \mathrm{PPQ}$ systems). XANES results corresponding to the first step of Cr deposition are reported hereafter.

XANES spectra were recorded for two X-ray incidence angles using two detection modes. For their interpretation, we have also studied reference molecules such as 2,2'-biquinoline (Fig. 2) or benzene [6]. 
Reference compound:<smiles>c1ccc2nc(-c3ccc4ccccc4n3)ccc2c1</smiles>

Fig. 2: Chemical structure of 2,2 '-biquinoline.

The XANES spectra of 2,2'-biquinoline on $\mathrm{Pt}(111)$ recorded in total yield detection mode at the $\mathrm{C}-\mathrm{K}$ edge are reported in figure 3 . As expected, the change from normal to glancing $X$-ray incidence induces a strong decrease in intensity for the first complex structure observed around $285 \mathrm{eV}$ and confidently assigned to $\pi$ - $\pi^{*}$ transitions. Indeed, as already observed with pyridine on $\operatorname{Pt}(111)$ system [7], heterocycles have preferentially their mean plane perpendicular to the substrate plane.

Fig 3: C-K edge spectra of 2,2'-biquinoline on $\mathrm{Pt}(111)$ with either normal (trace a) or grazing (trace b) incident X-ray relative to the surface.

\section{Pristine nolvmer surface:}

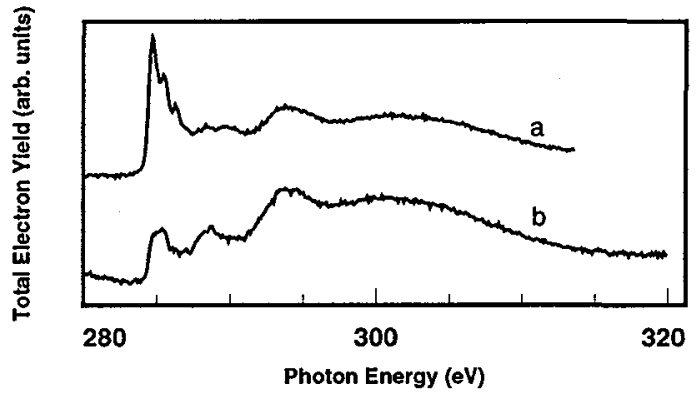

The first experiments on the pristine surface were carried out at the $\mathrm{C}-\mathrm{K}$ edge and at the N-K edge (Fig. 4) in total yield detection mode. They have revealed a preferential orientation of the rings of the polymer units parallel to the substrate plane [5].



Fig 4: Spectra in total yield detection mode of pristine PPQ with either normal (trace (a) for C-K edge and (a') for N-K edge) or grazing (trace (b) for C-K edge and (b') for N-K edge) incident X-ray relative to the surface of the substrate.

Now, upon using Auger detection mode and depending on the X-ray incidence, for the same PPQ pristine surface, two rather different spectra are obtained. The first one (Fig 5a), recorded in normal incidence, is similar to the spectra of a benzene monolayer on $\mathrm{Ag}(110)$ recorded in grazing incidence [6]. The second one (Fig 5b), recorded in grazing incidence has many strong analogies with the 2,2'-biquinoline spectrum recorded in normal incidence.

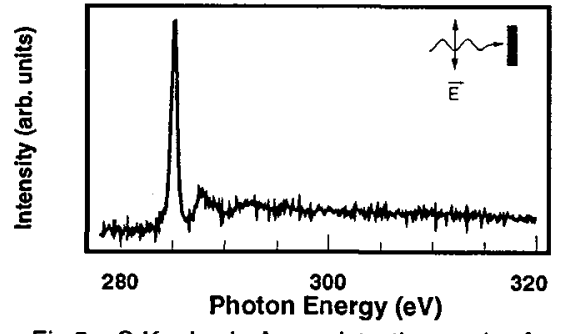

Fig 5a: C-K edge in Auger detection mode of pristine PPQ (normal incidence). 
Both observations are consistent with a special organization of the last polymer unit rings at the surface: phenyl rings seem to be perpendicular to the surface whereas quinoxaline units always stay parallel to this one.

Therefore two different detection modes, i.e: total yield and Auger have led to two different and apparently contradictory sets of results. We have interprated this apparent misfit in terms of difference in the electron mean free path: while a thickness of the order of $50 \AA$ is investigated in total yield mode, only $10 \AA$ or less are explored in Auger mode. Consequently, the peculiar orientation of the terminal phenyl rings of the last few layers of polymer becomes predominent only in the spectra recorded in Auger mode.

While the C-K edge appears to be extremely sensitive to the detection mode, the $\mathrm{N}-\mathrm{K}$ edge recorded in the Auger detection mode for magic angle $\left(54.7^{\circ}\right)$ is, in terms of lineshape and energy transition, quite similar to total yield observations (Fig. 6, spectrum a, to compare with Fig. 4). Moreover, the fact that our interpretation of the C$\mathrm{K}$ edge spectra only involves a special orientation of the last phenyl rings let us suppose that the nitrogen atoms (and the corresponding heterocycles) adopt the same orientation in the top layer than in the bulk of the polymer.

Fig 6: N-K edge spectra in Auger detection mode for magic angle of pristine PPQ (trace a) and chromium metallized PPQ (trace b).

\section{Chromium metallized surface:}

Chromium deposition was performed in the preparation chamber by exposing the sample to an e-gun evaporator. A particularly small deposit $\quad \approx 1$ monolayer) was studied in order to be more sensitive to the interface. For the same reasons, the detection mode used was the Auger one. After chromium deposition, only few intensity modifications were observed at the $\mathrm{N}-\mathrm{K}$ edge for magic angle (Fig. 6): we note an overall attenuation of the pristine $\mathrm{N}-\mathrm{K}$ edge which can be due to $\mathrm{Cr}$ adsorption on $\mathrm{N}$ sites.

Fig 7: $\mathrm{C}-\mathrm{K}$ edge for magic angle of -a: pristine PPQ (Auger detection mode), -b: PPQ upon Cr deposit (Auger detection mode), -c: PPQ upon $\mathrm{Cr}$ deposit (Total yield detection mode).

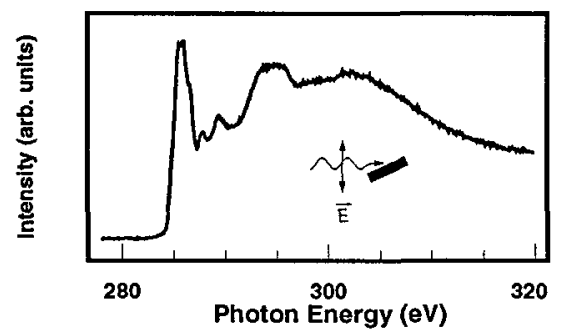

Fig 5b: C-K edge in Auger detection mode of pristine PPQ (grazing incidence) 
Moreover, $\mathrm{N}(1 s)$ spectra are strongly affected by $\mathrm{Cr}$ deposition as confirmed by Fig. 8. We observed the formation of a new structure at a lower binding energy $(\approx 398$ $\mathrm{eV}$ ) which corresponds in terms of energy to nitride-like species [8]. Again, C-K edge spectra, recorded in the same experimental conditions, appears to be much more sensitive, and strong modifications are observed upon chromium deposition.

Indeed, structures close to those observed in total yield detection are recovered (Fig. 7), revealing that changes in the orientation of the last polymer rings at the surface did occur. It reflects reorientations towards a more stable conformation. This is consistent with preliminary XPS results which suggest that chromium interacts with phenyl rings [9-11] so as to form a chromium $\pi$ complex where a chromium atom is centered above one phenyl ring.

As a matter of fact, we observed (Fig. 8) [11] the formation of an electron-rich carbon species which has a $C(1 s)$ electron binding energy of $283 \mathrm{eV}$ (whereas $\mathrm{C}(1 s)$ level of pristine surface is found at $285 \mathrm{eV}$ [12]).

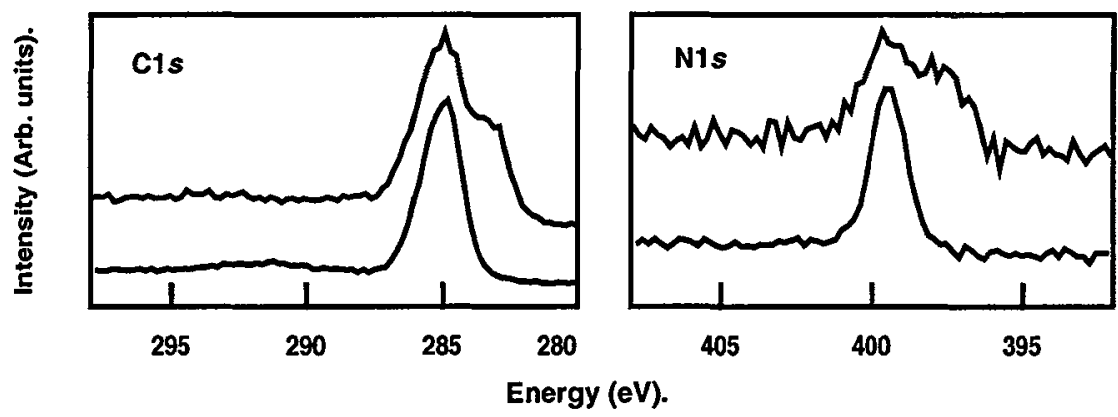

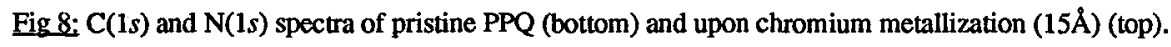

\section{Conclusion:}

C-K edge XANES studies carried out upon using various incidence angles and different detection modes have led us to stress the special behaviour of the terminal phenyl rings among the three different types of aromatic rings involved in the PPQ structure.

On pristine PPQ surface, these rings can rotate and adopt an "out of polymer unit mean plane" orientation. Then, upon interacting with first $\mathrm{Cr}$ monolayer, they return to the "in plane" in order to maximize the metal-ring interactions.

Further studies using comparisons between chromium-polymer interfaces and metalorganic reference compounds such as bis(benzene)chromium or benzene(chromium)tricarbonyl have to be undertaken soon.

\section{References}

[1] SILLION B. and VERDET L., in "Polyimides and other high temperature polymers" ed. by J.M.

Abadie and B.Silion, Elsevier 1991, p.363.

[2] BUREAU J.M., BERNARD F. and BROUSSOUX D., Revue technique THOMSON-CSF Vol. 20-

21, n4, Décembre 1989.

[3] SILLION B., Bul. Soc. Chim. Belg. Vol. 98/n²9-10/1989.

[4] FADDA E., BERENGER M. and VUILLERMOZ B., 9th international colloquium on PLASMA

PROCESSES, supplément à la revue "Le Vide, les Couches Minces", n²66, p. 259, Mars-Avril 1993.

[5] RICHARD G., CROS A., MATHEY Y., TOURILLON G., LAFFON C. and PARENT Y., Journal de Physique IV, Colloque C7, supplément au journal de physique III, volume3, novembre 1993.

[6] SOLOMON J.L., MADIX R.J. and STÖHR, Surface Science 255 (1991) 12-30.

[7] HORSLEY J.A., STÖHR J., HITCHCOCK A.P., NEWBURY D.C., JOHNSON A.L. and SETTE F., J. Chem. Phys. 83 (12), 15 December 1985. 
[8] HO P.S. , HAHN P.O., BARTHA J.W., RUBLOFF G.W., LEGOUES F.K. and SIL VERMAN B.D. J. Vac. Technol. A3, 739 (1985).

[9] JORDAN J.L., KOVAC C.A., MORAR J.F. and POLLAK R.A., Phys. Rev. B36, 1369 (1987).

[10] SELMANI A., OUHLAL A. and YELON A. in "Metallized Plastics 3: Fundamental and applied Aspects." ed. by K.L. Mittal, Plenum Press, New York, 1992, p.141.

[11] BELLARD L., THEMLIN J.M., PALMINO F. and CROS A., MRS Spring meeting, San Francisco, April 4, 1994.

[12] CROS A., DALlAPORTA H., LAZARE S., TEMPLIER F., NECHSTEIN J., PALLEAU J., HIRAOKA H. and TORRES J. in "Metallized Plastics 3: Fundamental and applied Aspects." ed. by K.L. Mittal, Plenum Press, New York, 1992, p.201. 